\title{
Correction to: CRISPR/Cas: a potential gene-editing tool in the nervous system
}

Yanxia Gao, Kexin Gao and Hui Yang ${ }^{*}$

\section{Correction to: Cell Regeneration (2020) 9:12}

https://doi.org/10.1186/s13619-020-00,044-6

Following publication of the original article (Gao et al. 2020 [1]), it is reported that the "Background" section and the heading "Main Text" need to be added to the article.

The Background section has been provided below.

Background

The CRISPR/Cas system is gaining more and more popularity in gene editing and therapy since first discovered in 1987. Up to now, on one hand, different types of the CRISPR/Cas system were discovered to improve its size, editing efficiency and PAM limitations; on the other hand, by fusing different factors to the mutant Cas protein which inactivates its nuclease activity but retains its ability to bind a specific DNA target site by a guide RNA, different types of engineered CRISPR/Cas9 tools were developed to perform modification of a specific gene, like DNA methylation or demethylation, histone acetylation or deacetylation and so on. Here, we briefly introduce these tools and their applications in the nervous system.

The original article (Gao et al. 2020 [1]) has been updated.
Reference

1. Gao Y, Gao K, Yang H. CRISPR/Cas: a potential gene-editing tool in the nervous system. Cell Regen. 2020;9:12. https://doi.org/10.1186/s1316 19-020-00044-6.

Published online: 13 October 2021

The original article can be found online at https://doi.org/10.1186/s13619020-00044-6.
*Correspondence: huiyang@ion.ac.cn

Institute of Neuroscience, State Key Laboratory of Neuroscience, Key

Laboratory of Primate Neurobiology, CAS Center for Excellence in Brain

Science and Intelligence Technology, Shanghai Research Center for Brain

Science and Brain-Inspired Intelligence, Shanghai Institutes for Biological

Sciences, Chinese Academy of Sciences, Shanghai 200031, China original author(s) and the source, provide a link to the Creative Commons licence, and indicate if changes were made. The images or other third party material in this article are included in the article's Creative Commons licence, unless indicated otherwise in a credit line to the material. If material is not included in the article's Creative Commons licence and your intended use is not permitted by statutory regulation or exceeds the permitted use, you will need to obtain permission directly from the copyright holder. To view a copy of this licence, visit http://creativecommons.org/licenses/by/4.0/. The Creative Commons Public Domain Dedication waiver (http://creativeco mmons.org/publicdomain/zero/1.0/) applies to the data made available in this article, unless otherwise stated in a credit line to the data. 